\title{
Development of methods for assessing the mine workings stability
}

\author{
Arstanbek Abdiev ${ }^{1 *}$, Rakhat Mambetova ${ }^{2}$, Aziz Abdiev $^{3}$, and Sher Abdiev ${ }^{4}$ \\ ${ }^{1}$ Kyrgyz State Mining University, Department of Opencast Mining and Blasting, 215 Chuy Ave., \\ 720001 Bishkek, Kyrgyzstan \\ ${ }^{2}$ Kyrgyz-Russian Slavic University, Department of Building, 44 Kievskaya street, 720044 Bishkek, \\ Kyrgyzstan \\ ${ }^{3}$ Kyrgyz State Mining University, Department of Surveying and Mine Surveying, 215 Chuy Ave., \\ 720001 Bishkek, Kyrgyzstan \\ ${ }^{4}$ State Agency for Architecture, Construction and Housing and Communal Services under the \\ Government of the Kyrgyz Republic, Department of Architecture and Technical Regulation, \\ 28 Manas Avenue, 720001 Bishkek, Kyrgyzstan
}

\begin{abstract}
This paper studies the rock mass stress state under highland conditions, depending on the geological structure of a particular rock mass area, the tectonic field of stresses and the region relief. This study is aimed to develop an experimental method for assessing and monitoring the properties and state of the rock mass adjacent to mine workings. Experimental studies are performed through stresses measurements in-situ. Based on research results, it has been revealed that the geological structures, tectonic fields of stresses and the earth's surface relief of the deposit normally reflect the values and direction of the main stresses acting in the mass. These patterns can be used to predict and assess the stress state of the rock mass. During the mass stress state assessment, quantitative dependences have been obtained for determining the stress tensors conditioned by the overlying rocks weight, tectonics and fracturing, and the deposit surface relief The research results make possible to assess the nature of the stresses distribution, to identify the areas of reduced, equal, increased and maximum stresses concentration of the virgin mass, as well as to increase the efficiency of the geoacoustic control developed by the authors for the state of the mass adjacent to mine working. According to the new patterns and dependences obtained, the values and directions have been scientifically determined of the main stresses action, as well as the zones of stresses manifestation. These patterns and dependences are valuable for designing and planning the development of mining operations.
\end{abstract}

\section{Introduction}

Construction and exploiting the engineering structures on the day surface (quarries, hydroand irrigation units, railroads and automobile roads) and underground (tunnels, mine shafts, aqueducts and other mine workings) are related to mining operations and mining-

\footnotetext{
*Corresponding author: abdiev arstan@mail.ru
} 
construction activities in rocks mass. The main feature is to create outcroppings in them. These complex systems of outcroppings in the form of mine workings for various purposes disturb the natural stress state of rocks [1].

The nature of changing stress states and the occurrence of deformation processes differ by their considerable variability and complexity, caused by heterogeneous composition, structure and properties of the rocks, as well as the diversity of sizes and the relative positions of outcroppings [2-4].

Observations indicate that the collapse of more or less significant mass area is preceded by local destructions, changing outcropping stability as a whole [5]. In case of further local destructions development, when their separate areas begin to converge, there arise the intensely growing deflections of outcroppings, rocks parting, exposure of existing and the occurrence of new fractures, the mutual intersection of which leads to the formation of fragments with various shapes that lose coherency with the mass, and their gradual or sudden collapse $[6,7]$.

The rock pressure is evident in the form of collapsing, displacements, falls, outbursts, bumps and impacts in rocks - the final stages of deformation and destruction processes [8]. Solution to a large number of important practical mining problems is related to patterns of these processes development.

Therefore, to obtain relevant information, experimental methods should be used to study the state of the rocks under in-situ conditions. Mechanical methods for studying the mass are characterized by high complexity and the impossibility of repeated measurements at the studied point [9]. This is the basis for searching and developing other methods.

Recently, geoacoustic methods (ultrasonic, seismic, and acoustic) have been introduced into the practice of geomechanics research. These methods make possible to determine the thickness, occurrence, depth and area of zones and cavities inaccessible for direct investigation, as well as other properties and states of rocks without the mass discontinuance $[10-13]$.

The works [14-17] have greatly contributed to the theory and practice of the geoacoustic methods development. The efficiency of geoacoustic control for the mass state is determined by two groups of factors: a set of mining-and-geological conditions of the object and the level of equipment and measuring instruments development. It is possible to achieve the maximum effect of control only when the main factors of both groups are properly taken into account $[18-22]$.

The research object of this work is the most important factors of the first group. At the same time, the main aspect of the problem is highlighted - to reveal the dependences of the rock mass stress state on the structural and mining-engineering peculiarities in a framework of an integral production facility.

\section{Methods}

The Earth's crust is composed of rocks, diverse in origin and composition. This paper is focused on the hard rocks study.

Hard rock is a medium with heterogeneous structure and properties both in space and over time. The indicators of the mass physical properties, as a rule, are different at its different points, moreover, anisotropy of these indicators manifestation and distribution in space is noted at the same point [23-27]. These are the main peculiarities of the internal hard rock structure. It should be noted that in this particular case, mechanical anisotropy is studied.

Isotropic areas of the hard rock mass, when its material in all directions in space reveals the same properties, with equal intensity occur much less often than anisotropic ones.

Heterogeneity of the hard rock mass is manifested in the form of fracturing, stratification, the presence of inclusions and cavities, stress state, etc. By the degree of 
opening, fractures in mine rocks vary within wide limits, from $10^{-7} \mathrm{~cm}$ to tens of meters. In terms of the genesis, there are fractures of forming, deformation fractures, and weathering fractures. These systems are often superimposed on one another and it is not always possible to differentiate them in in-situ conditions. Dimensions of inclusions and cavities in the mass range from $10^{-1} \mathrm{~cm}$ to several tens or hundreds of meters. The zones of stresses concentration in the rock mass range from tens of centimetres to several tens of meters.

A distinctive hard rocks peculiarity is their increased strength, low compressibility and low permeability within the mass. The strength of the hard rock in a piece without fractures and unexposed to weathering processes depends on the type and genesis of the rock.

Effusive igneous rocks have the greatest compressive resistance (from 1000 to 4000 $\mathrm{kg} / \mathrm{cm}^{2}$ ). Compressive resistance of metamorphic rocks is also very high: for gneisses, crystalline schists, quartzites, it is $1000-3000 \mathrm{~kg} / \mathrm{cm}^{2}$. Hard rocks of sedimentary origin have a slightly lower compressive resistance: from 60 (gypsum, salt rock) to $1200 \mathrm{~kg} / \mathrm{cm}^{2}$ (strong limestones, dolomitic rocks, conglomerates and sandstones).

The technical hard rocks properties are described sufficiently well in the works [24, $26,27]$, where the theories of variability of the mine rocks properties and structure are developed. Based on them, a conclusion can be drawn about two components of the composition and properties variability. Firstly, the process of forming the composition and properties of mine rocks is not completely determined and is always complicated by the random factors influence. Secondly, the indicators of the mine rock mass composition and properties in the general case are compositions of deterministic and random fields.

The rock mass calculation for strength is inextricably linked with its stress state determination, since the initial stress state is specific to all virgin rock mass, not weakened by mine workings. Additional impact on the mine rock mass will only modify the stress state, and not create it again. Therefore, it is necessary to study the mass stress state not only for the purpose of identifying a dangerous point and the stress state component in it, but also for assessing the rocks strength at this point. Since, most of the criteria for the occurrence of the dangerous geomechanical state are expressed precisely through the stress state components.

\section{Results and discussion}

\subsection{Research into the stress state of rocks in the virgin mass}

Analytical studies on assessing the rock stresses in the mass caused by constantly and generally acting factors are performed by the methods of continuum and discrete medium mechanics. Attempts are being made to construct additional stress fields generated by factors acting temporarily or locally. There are certain difficulties in this direction. Firstly, there have not been developed any reliable and unified agreed concepts on the origin and peculiarities of the earth's crust development, which could confidently become the basis for an analytical research. Secondly, insufficient knowledge of the mechanical properties of mass does not allow to select the optimal research methodology and provide stresses calculations with the initial data. Thirdly, the very nature of forming and development of force fields in heterogeneous and variable mass, exposed to numerous external impacts, is too complex.

In-situ measurements at different points of the Earth have revealed that stress occurs in the virgin rock mass. Stress fields in mass are formed under the influence of gravity, tectonics, physical and mechanical properties of mine rocks, surface relief, geological, geophysical, geomechanical, geodynamic and geochemical processes, human production activity and other factors. And they are changed both in space and over time.

By analysing the experimental data [28], two types of stress state fields in mine rock mass are distinguished: geostatic and geodynamic. 
In the case of geostatic stress fields, they mainly correspond to the formulas of A.N. Dinnik, G.A. Krupennikov and S.G. Lehnitskiy:

$$
\begin{gathered}
\sigma_{z}=\sigma_{x}=\sigma_{y}=\gamma H ; \quad \tau_{x y}=\tau_{x z}=\tau_{y z}=0 ; \\
\sigma_{z}=\gamma H ; \quad \sigma_{x}=\sigma_{y}=\frac{\mu}{1-\mu} \sigma_{z}=\lambda \gamma H ; \quad \tau_{x y}=\tau_{x z}=\tau_{y z}=0 ; \\
\sigma_{z}=\gamma H ; \quad \sigma_{x}=\sigma_{y}=\frac{\mu_{2}}{1-\mu_{1}}=\frac{E_{1}}{E_{2}} \cdot \frac{\mu_{3}}{1-\mu_{1}} \sigma_{z} ; \quad \tau_{x y}=\tau_{x z}=\tau_{y z}=0,
\end{gathered}
$$

where $\sigma_{z}, \sigma_{z}, \sigma_{y}$ are normal vertical and horizontal stresses; $\tau_{x y}, \tau_{x z}, \tau_{y z}$ are shear stresses; $\gamma$ is bulk density; $H$ is the depth of the studied point of mass; $\mu_{1}$ is Poison's ratio, characterizing the contraction in the plane of isotropy under tension in the same plane; $\lambda$ is side thrust coefficient; $\mu_{2}$ is Poison's ratio, characterizing the contraction in the plane of isotropy under tension in the direction perpendicular to this plane; $E_{1}$ is Young's modulus under tensioncompression in the plane of isotropy; $E_{2}$ is Young's modulus under tension-compression in the plane perpendicular to the plane of isotropy.

The results of measurement, performed in sedimentary rocks of the Lviv-Volyn Coal Basin at a depth of $330-536 \mathrm{~m}$ [29], in coal-bearing strata of the Kuznetsk Basin at a depth of $80-240 \mathrm{~m}$ [30], at a depth of $262-380 \mathrm{~m}$ of the Vyisokogornyiy iron ore deposit and at a depth of $110-712 \mathrm{~m}$ of the Kochkarsky deposit [31], approximately correspond to such conditions.

The observed local deviations of $\sigma_{z}, \sigma_{z}, \sigma_{y}$ from the values indicated in dependences (1)(3) are possibly explained by occurrence of stresses conditioned by the acting tectonic forces, the result of stress relaxation, as well as neglecting the heterogeneity in mechanical properties of various rocks, etc.

Geodynamic fields of stresses are characterized by sharply increased values of horizontal (and sometimes vertical) compressing stresses. Usually, their significant anisotropy is also observed.

Horizontal stresses often by $50-200 \mathrm{~kg} / \mathrm{cm}^{2}$ exceed the value of geostatic pressure $\gamma H$, revealing connection with neotectonics. Geodynamic fields have been identified in the Hibinskiy mass on the Kola Peninsula [32], in Dzhezkazgan in Kazakhstan [33], in the Temirtau and Tashtagol deposits in Mountain Shoriya [34], in the mines of the Urals [35], in the areas of the construction of the Sayano-Shushenskaya hydroelectric power station on the Yenisei river, Toktogul hydroelectric power station on the Naryn river [36], in the deposits of Kyrgyzstan and in other areas [36].

In the works $[32,37]$, options are proposed for an analytical and experimental solution to the problem of stresses distribution in a virgin rock mass taking into account the acting tectonic forces in the following form:

$$
T_{g}+T_{t}=\left\|\begin{array}{lll}
k_{1} \sigma_{g} & 0 & 0 \\
0 & k_{2} \sigma_{g} & 0 \\
0 & 0 & \sigma_{g}
\end{array}\right\|+\left\|\begin{array}{lll}
\psi_{1} \sigma_{t} & 0 & 0 \\
0 & \psi_{2} \sigma_{t} & 0 \\
0 & 0 & \sigma_{t}
\end{array}\right\|,
$$

where $T_{g}$ is gravity stresses tensor; $T_{t}$ is tectonic stresses tensor; $k_{1}, k_{2}$ is lateral repulse coefficients in the field of gravitational forces; $\psi_{1}, \psi_{2}$ is lateral repulse coefficients in the field of tectonic forces.

Tectonic stresses characteristic of geodynamic fields as usual increases with a depth by linear law.

The gradient of stresses change at $1 \mathrm{~m}$ depth is [37]: 
a) for the field of gravitational forces: $\overline{\Delta \sigma_{g}}=0.1 \gamma \mathrm{kg} / \mathrm{cm}^{2} / 1 \mathrm{~m}$;

b) for the field of tectonic forces: $\overline{\Delta \sigma_{t}}=\frac{\Delta \sigma_{t}}{\Delta H} \mathrm{~kg} / \mathrm{cm}^{2} / 1 \mathrm{~m}$.

where $\Delta \sigma_{t}$ is tectonic stresses increment in the increment interval in meters of depth $\Delta H$.

The results of stresses direct measurements in the mine rock mass of the upper part of the earth's crust evidence a large propagation of geodynamic stress fields already at a shallow depth. In general, the occurrence and redistribution of the natural field of stresses of a virgin rocks mass in the earth's crust, where mining operations and mining-construction activities are conducted, is a multifactorial and multi-stage process. Stresses are variable in space and in time. The mass initial stress state significantly influences on the forms of the rock pressure manifestation in the course of conducting and exploitation of various mine workings.

\subsection{Stress field in the rocks adjacent to mine workings and methods for study}

Mining operations and mining-construction activities are accompanied by complex changes in the natural stresses distribution in the mass adjacent to outcroppings. That is, there is a complex and heterogeneous stress state that varies from uniaxial or biaxial compression on the contour of outcropping to triaxial non-uniform compression at the mass depth. And, in order to assess outcroppings stability, it is necessary to determine the stresses and displacements that occur in the mine rock mass influenced by conducted operations [38 - 40].

Methods for assessing stresses and displacements of the rock mass are divided into three classes: in-situ mine measurements (method of unloading, pressure differential, boreholes, seismoacoustic, radioelectrometric, etc.); laboratory-based experiments (photoelasticity method, modelling on equivalent materials, centrifugation method, tensometric mesh method, electro-hydrodynamic analogies, etc.); calculation studies (methods of elasticity theory, finite elements, compensation loads of the negative forces application, etc.).

Studying the stress state of rocks by various methods is quite effective, since they complement each other and make it possible to more completely assess the general stress state of the mass adjacent to outcroppings. However, each of these methods has limits of application and capabilities.

One of the first hypotheses explaining the work conditions of roof rock cropped out by mine workings was the girder hypotheses presented and developed in the work [41]. It is assumed here that the work of the roof in the stope faces, represented by hard laminal rocks, is very similar to the work of girders. To determine the stresses arising in the girderslayers, it is proposed to use the well-known construction mechanics formulas.

This hypothesis has not been implemented because of the controversial initial position, the difficulties in dividing the mass into separate layers and determining the actual tensile strength of rocks in each layer. Nevertheless, the work [41] is a great step forward in solving the issues of the rock pressure. The author of [41] distinguishes the conditions of a stable and unstable roof state, the importance of considering the mass structural peculiarities. In addition, he presents a unified rock pressure hypothesis for preparatory and stope mine workings, which is completely substantiated by the unified physical nature of its development in both cases.

The pressure arch hypothesis, which has not lost its significance today to explain some processes of the rock pressure manifestation when mining the sedimentary and ore deposits, is rather widespread [42]. It lies in the fact that in the mass, when the stope face advances, a zone of increased confining pressures is formed, which has the shape of an arch. Between this arch and the mined-out space, there is an area of low stresses, and only the rocks located inside the arch contour put pressure on the support [43-45]. As evidenced in practice, the pressure arch hypothesis is characteristic of the first period of the longwall 
faces operation, when the collapse and displacement of the rocks did not reach the surface. Then, there is a deflection in the stratum or block caving of the rocks in direction of fractures. The pressure arch formation is a form of the mass stress state manifestation, which cannot serve the basis for creating a general rock pressure theory.

The concept of the predominant influence of the mass structural peculiarities, expressed in ideas about the certain areas formed in the undermined mass, the rock elements interaction with each other and with the support of the stope workings, is embodied in the theory of "block" roof caving [46]. The theory was exceptionally important for the interpretation by various researchers of the processes occurring in the mass during the underworking, the synthesis of ideas about the rock pressure manifestation mechanism not only when mining the hollow-bored, but also steeply dipping deposits, as well as for stabilization of views on the work conditions of the stope working supports [47]. However, it should be noted that the theoretical developments and calculations [46] study the consequences caused by changes in the stress state of the rock mass during mining operations. Continuum mechanics methods are widely used in mining practice to calculate stresses and displacements in the mass influenced by mine workings. Based on the obtained distribution of these values according to various criteria of strength and stability, a conclusion can be drawn on the mass behaviour and the mine workings safety.

The stress field around mine workings of various configurations is well studied through the mathematical theory of elasticity, plasticity and photoelasticity. However, these methods are developed on the basis of a certain idealization of environmental conditions, which means that the rocks are assumed to be an elastic, homogeneous isotropic medium. Therefore, these methods cannot take into account the whole variety of geomechanical and mining-engineering factors. In this regard, the analytical and experimental method is of interest [48], which is based on the application of an analytical solution, using, as boundary conditions, actual data on the displacements of roof rocks along the contact with the seam and above the mined-out space. Conditioned by the introduction of experimental data, this method takes into account a combination of mining-and-geological and mining-engineering factors. At the same time, the information is widely used, contained in the experimental data, since by means of analytical calculations it is possible to obtain an assessment of the entire mass area state. Nevertheless, this method cannot solve the problems for heterogeneous, in particular, laminal mass; mine workings with complex configuration cannot be studied. Finally, the experimental determination of the values necessary for introduction into the boundary conditions is associated with considerable difficulties [49-53].

Along with elastic and elastic-plastic solutions, solutions are developed that take into account the time factor, based on creep theory and rheological concepts [54, 55]. Rock mass is characterized by elastic constants and a hereditarity core in the form

$$
r(t)=a_{1} e^{-B_{1} t}+a_{2} e^{-B_{2} t},
$$

where $\alpha_{1}, \alpha_{1}, B_{1}, B_{2}$ are experimentally determined parameters.

The creep theory is successfully used in the works $[54,55]$ to analytically solve many problems of mine rock mechanics, which made it possible to obtain results related to the study of stresses and displacement fields of mass adjacent to various structures under conditions of mine rocks creeping and relaxation.

In general, computational methods cannot yet fully satisfy the needs of designers and experts, since the stress field in the mass, caused by the influence of various factors, is complex and diverse. Therefore, the most correct analysis and assessment of the certain mass area state is possible using in-situ observations and direct measurements of stresses and displacements. In-situ measurements reveal the dominant factors and correctly formulate the initial and boundary conditions for setting the correspondent problems solved by other methods. 
The main method for measuring the stresses in the mass is the de-stressing method, options from the All-Russian Research Institute of Mining Geomechanics and Survey, N. Hast, L. Obert, partial balancing of Liman, and others.

All of the above methods have major deficiencies: the complexity, the impossibility of multiple measurements at the same point of the studied mass and obtaining the information on the change in stress over time. This is the basis for more effective methods development, primarily geophysical [56,57], based on the dependence of the mine rocks physical properties on pressure. One such method is the geoacoustic method.

The geoacoustic method means obtaining the acoustic characteristics of the rocks in the studied mass area and processing these data using calibration dependences on pressure for the same rocks. The mass acoustic parameters are measured by profiling method and sounding method. During the longitudinal profiling of wells, the walls structure has a greater influence, therefore, it is advisable to use it in the study of fracturing of rocks adjacent to the well. Using the sounding method, it is practically possible to exclude the zone of wells influence.

To determine the mine rock mass stress state using the sounding method, it is necessary to know the influence of humidity, temperature, porosity and fracturing on the acoustic characteristics of rocks. Fracturing is the most difficult to consider. When the stresses in the mass increase, the velocities of elastic waves increase and their attenuation decreases, and with an increase in fracturing, the reverse process occurs. In recent time, to characterize fracturing, the methods of geoacoustic studies are used in a wide frequency range with analysis of the applied elastic vibrations spectrum and identification of single fractures, as well as their systems using the hodograph and amplitude graph [58 - 60].

The geoacoustic measurements in the mass are interpreted either by unloading the mass block with subsequent its loading using hydraulic jacks or hydraulic cushion, or using graphs or dependences obtained through laboratory tests.

In laboratory calibration, the phenomenon is used of occurring the high-velocity anisotropy in rock samples in the course of their loading. The dependence of the elastic waves parameters on the pressure in the samples is determined in two directions: at unidirectional and confining pressure.

Despite the above theoretical and experimental studies on setting the link between the measurements of elastic waves parameters and pressures, at present there is still no single theory that could completely explain the mine rocks behaviour depending on pressure. There is no information on the reliability of the application area for geoacoustic method.

The experimental data analysis on the study of the stress state in the mass adjacent to mine workings has revealed that the tension zone nature depends on the method of the mine working development and the geological conditions of the rocks occurrence. At all mines, pits, except for the salt mines, there is a low stresses zone adjacent to mine workings (Figs. 1-3).

The size of this zone is determined by the rocks property. The zone of low stresses is propagated into the depth of the mass from the mine working wall by $0.5-2 \mathrm{~m}$. The occurrence of the low stresses zone is explained by the fact that when conducting blasting operations, the rocks near the mine working walls are destroyed [61 -63].

The maximum stress values are observed at a certain distance from the mine working contour. The stress-concentration factor varies in wide range. Its value is determined by mechanical properties of the rocks and mine working parameters. In case of the Lviv-Volyn Basin, the zone of mine working influence on the stress field was $2.5-3.5 \mathrm{~m}$ from the wall of mine working, with its width from 3.2 to $6.3 \mathrm{~m}$. In the Donetsk Basin it was $3-5.5 \mathrm{~m}$ with a mine working width from 3 to $7.6 \mathrm{~m}$.

Experimental studies suggest that there is some difference between the stress field around the mine working, determined by the elasticity theory methods, and the field obtained by in-situ measurements, although the general patterns are kept. 


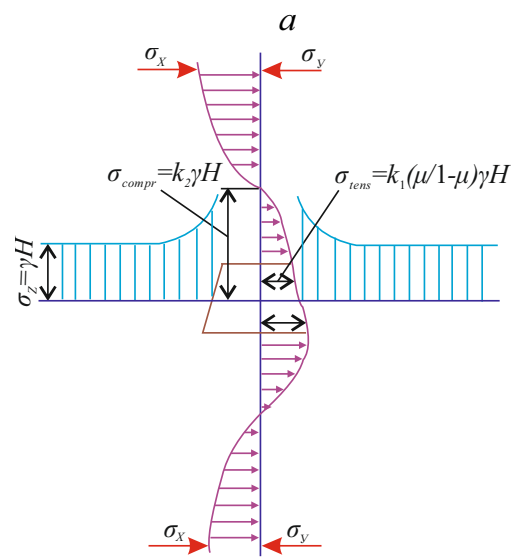

Fig. 1. Theoretical $(a)$ and actual $(b)$ stresses distribution around the trapezium-shaped mine working: $\sigma_{\text {tens }}-$ tensile stresses value; $\sigma_{\text {compr }}-$ compressive stresses value; $k_{1}, k_{2}-$ stress-concentration factor.

$a$

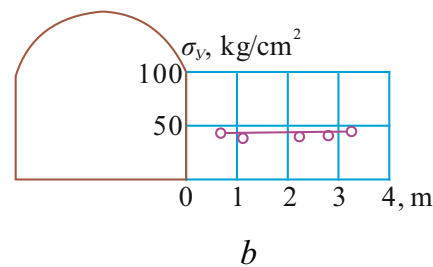

$b$

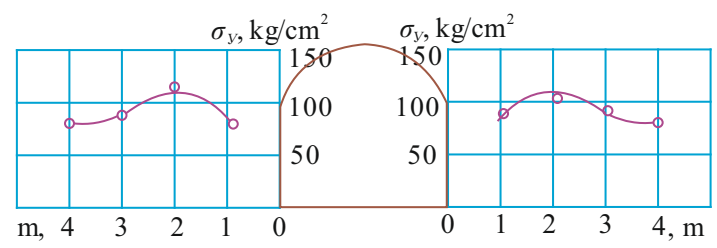

C

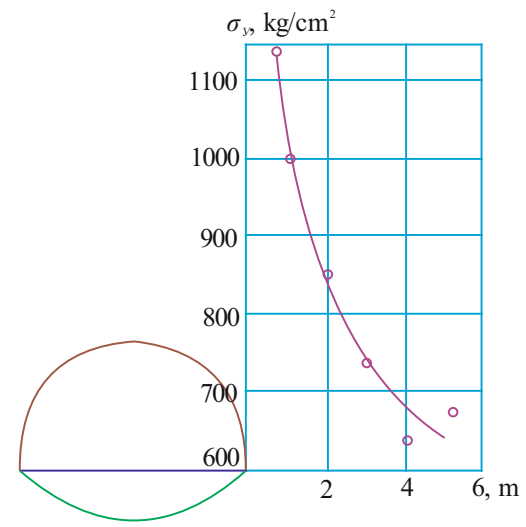

Fig. 2. Stress curves in the walls of horizontal mine workings [29]: $a$ - "Silvik" mine, below field datum $225 \mathrm{~m}$, potassium salt; $b$ - "Novovolynskaya" No. 6 mine, below field datum $330 \mathrm{~m}$, argillaceous shale; $c$ - "XXII s'ezda KPSS" mine, below field datum 913 m, sandstone.

The differences are as follows. The stress maximum is not on the mine working contour, but at a certain distance from it, the stress-concentration factor is lower than according to theoretical data. In some mine rocks, such as salt, stress concentration does not arise around mine workings.

In general, full-scale methods are important for identifying the absolute level of the stress state of mass characterized by certain features of the geological structure and technology of work. In general, in-situ methods are important for identifying the absolute level of the stress state of mass characterized by certain peculiarities of the geological structure and technology of mining operations.

However, they have several disadvantages. Firstly, measurements are made at a limited number of points and it is difficult on their basis to recreate a pattern of the mass stress state as a whole. Secondly, they can be conducted only in the process of mining operations. Thirdly, the methods themselves are still far from perfect in terms of reliability and accuracy of measurements, and the results obtained with their help should be compared with the results of other methods. 


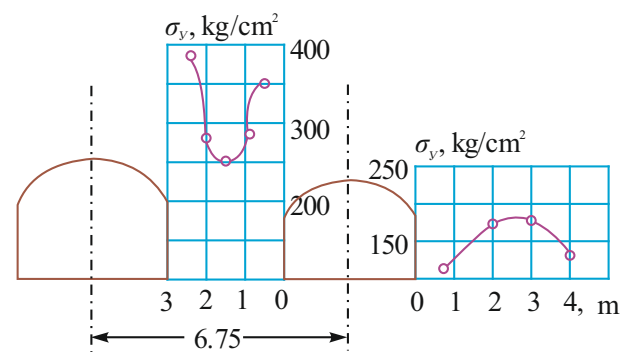

$b$

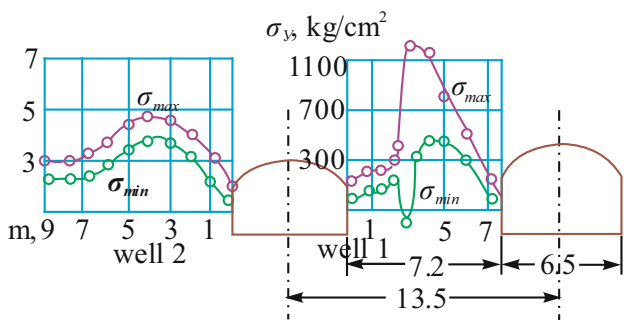

$c$

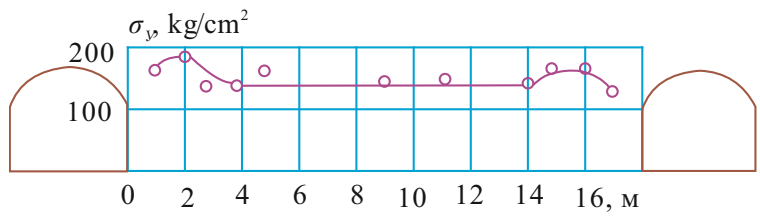

Fig. 3. Stress curves in pillars of various widths: $(a)$ and $(b)$ - "Velikomostovskaya" № 6 mine [29], below field datum 536 m, sandy shale; (c) - "Kirova" mine (Krivoy Rog).

All the above difficulties in studying the stress fields in the mass adjacent to mine workings are caused by the structure and state of real mine rock mass, which are always more complicated than theoretical schemes and models. This will be demonstrated using the example of the Tien Shan in Kirghizia.

\subsection{Specifics of the rock pressure manifestation under highland conditions}

Kyrgyzstan is located within the Tien Shan folded area. The entire territory of the republic is above $500 \mathrm{~m}$ above sea level. The mountain ranges are about $3 / 4$ of the territory and extend in parallel chains mainly in the latitudinal direction.

The Tien Shan folded upheaving on the territory of the geosynclinal system did not occur simultaneously [64]. Important elements of the Tien Shan regional structure are large fragments, blocks of folded structures of previous epochs of development, organically not connected with the fold systems structures enclosing them. The blocks of ancient folded complexes have been processed by younger movements in varying degrees, but on the whole they represent relatively stable areas of the earth's crust as median mass.

The main features of the modern Tien Shan relief were formed at the end of the Pleiocene - Early Quaternary. Within the Tien Shan of Kirghizia [24-26, 65-70], the systems of upheavings and depressions of almost latitudinal strike have been identified, which are the main recent structural forms. Recent deformations are characterized by flat-lying earth's crust bends, complicated by many internal failures, as well as zones of edge and transcurrent regional faults (Fig. 4). The systems of upheavings include relatively small and narrow, highly elevated, reduced intramountain depressions, which experience relative deflection against the background of a general intensive upheaving. Structurally, the most significant upheavings are meganticlines and highland-meganticlines. Flat-lying large bends have a folded-block structure. On the whole, the general character of the recent Tien Shan structure is defined as folded-block. The complex geological region structure is also manifested in ore occurrences [71]. Ore and coal deposits are currently being exploited. Tremendous reserves of bituminous and brown coals, oil and gas, promising deposits of stannum, nepheline syenites, non-ferrous, precious and other metals, as well as various raw materials for the building materials industry and the chemical industry have been identified and explored. 

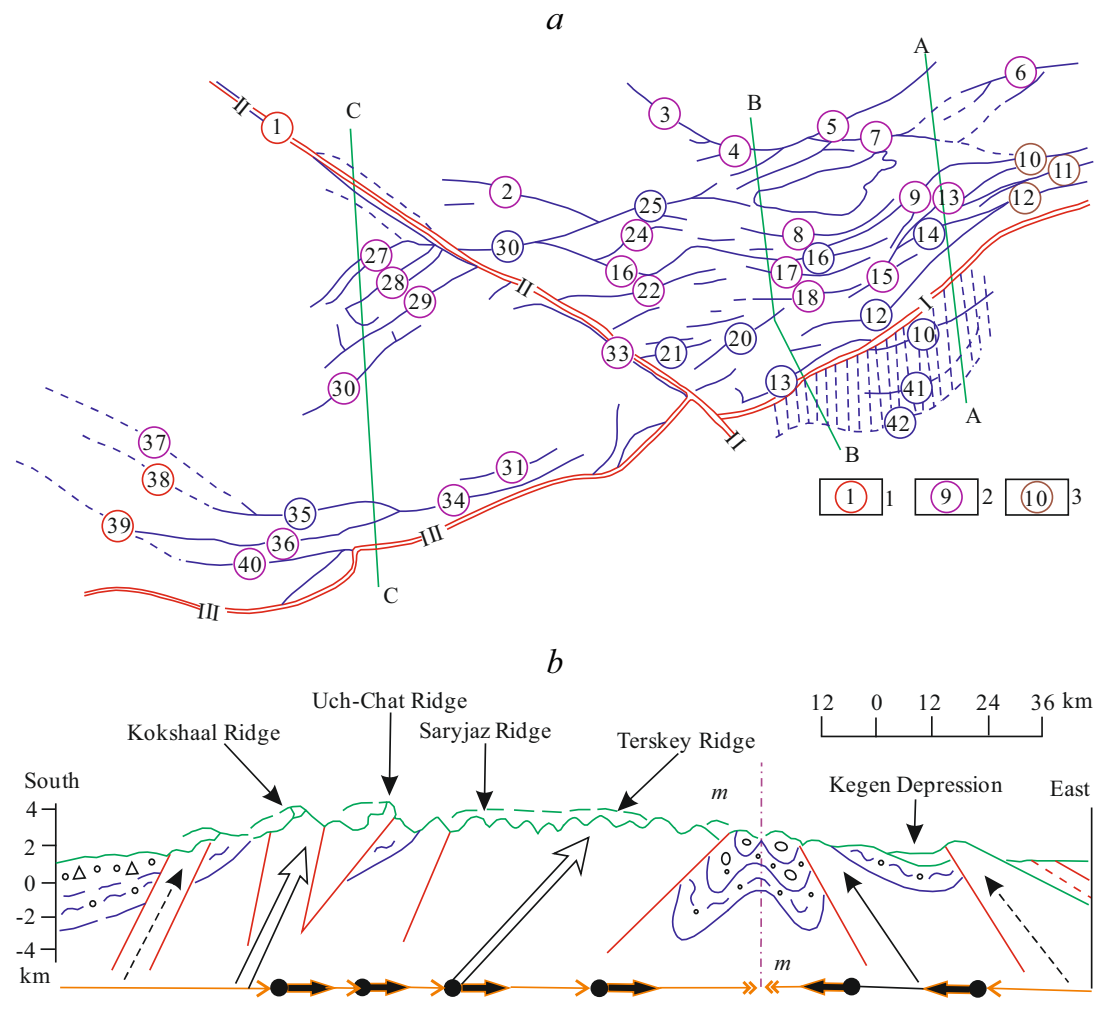

c
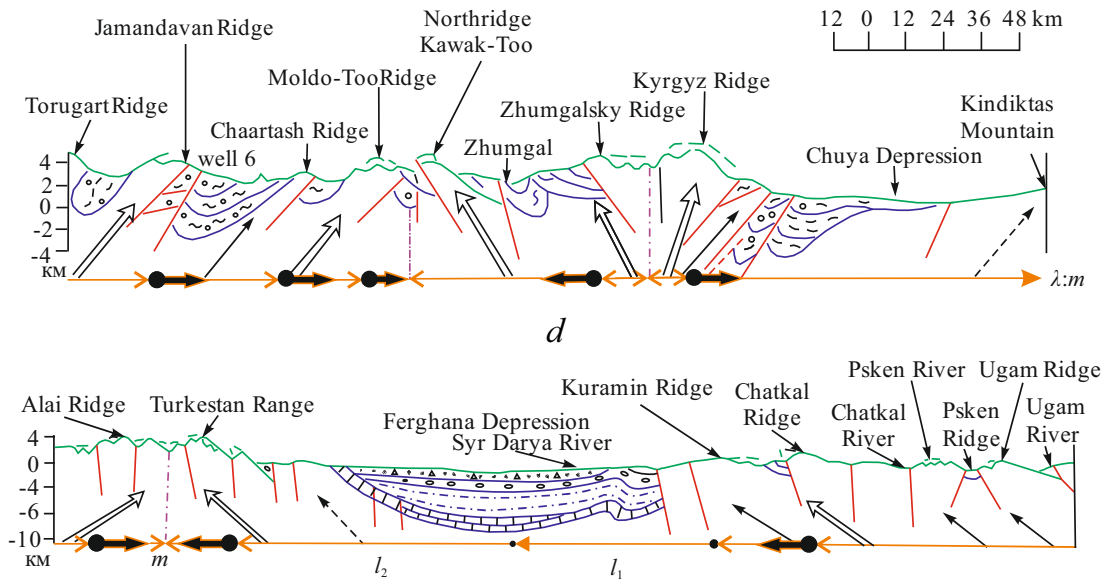

Fig. 4. Scheme of Kyrgyzstan neotectonic: $(a)$ - The meganticlines axes layout of the Tien Shan: (b) - meganticlines raised to $3000 \mathrm{~m}$; (c) - meganticlines raised from 3000 to $5000 \mathrm{~m}$; (d) meganticlines raised to $5000 \mathrm{~m}$ and more; deep-seated faults: I - Kokshalsk, II - Talas-Ferghana, III - Gisaro-Vostochno-Altai.

Numerous data on the dislocations of the youngest sediments and disturbances in the recent topography, as well as high seismicity [24, 26, 65-70] indicate that the processes of the Tien Shan structures formation continues even now (Figs. 5 and 6). 


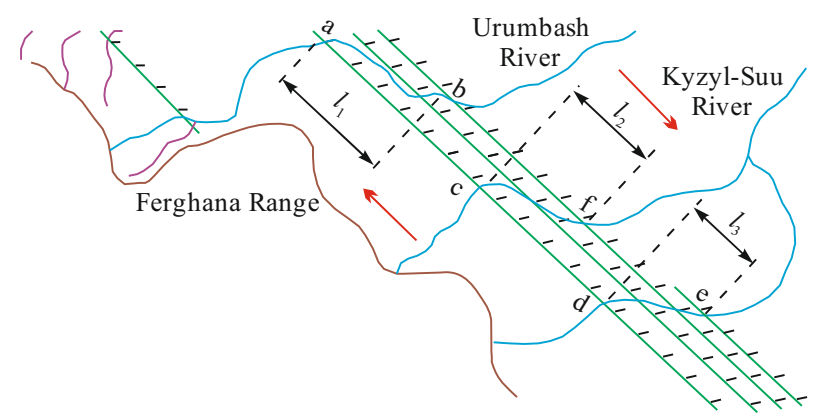

Fig. 5. Indications of the horizontal earth's crust movements in the drawing of the river network in the area of Talas-Ferghana fault $[24,26,70]: l_{1}$ - horizontal displacement amplitude in the valley of the Urumbash River, between points a and $\mathrm{b} ; l_{2}$-the same in the valley of the Kyzyl-Suu River, between points $\mathrm{c}$ and $\mathrm{d} ; l_{3}-$ the same between points $\mathrm{e}$ and $\mathrm{f}$.

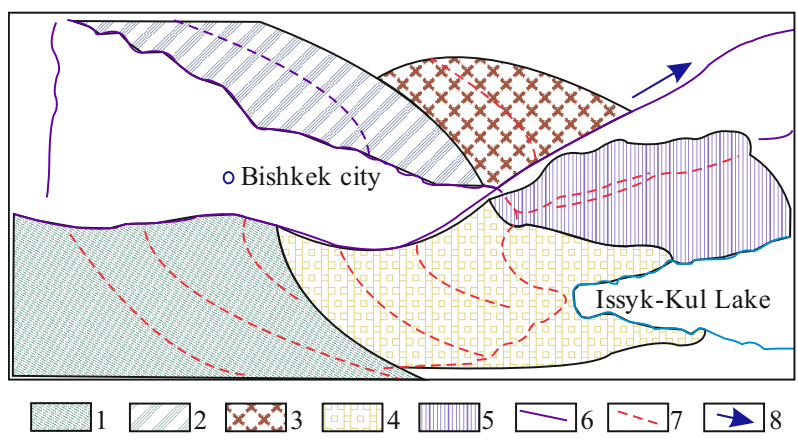

Fig. 6. Scheme of the tangential slip along the North Tien Shan fault, zones [24, 26, 70]: 1 - Central Kyrgyz; 2 - Kindiktas; 3 - Vostok-Kyrgyz; 4 - Ili; 5 - Keminsk; 6 - North Tien Shan fault; 7 - General trends of Caledonian structures; 8 - relative tangential slip direction.

The rich hydropower mountain rivers resources are being developed. The mountain roads and tunnels are being constructed and reconstructed. In the conditions of the Kyrgyzstan highlands, when designing, constructing and, exploiting engineering structures on the surface (dams, quarries, opencasts, roads, etc.) and underground (tunnels, mine workings, chambers, etc.), hard rock mass properties and conditions are the key to understanding and solving a number of critical issues of technology and safety during mining operations. Thus, the hard rock mass stress state in the river valleys, where roads or dams are built, is distinguished by a certain peculiarity.

The slopes are geological objects complex by structure and history of formation.

The studies [24, 26, 72-74] have revealed, that the stresses distribution is complex in the mountain slopes and at the base. In the mass of the slope, there is a zone I of decreased stresses, which is a result of unloading towards the valley of the part adjacent to the slope. It gradually changes into the zone II of increased stresses (Fig. 7).

In zone II, the vertical stresses exceed the values of the same stresses calculated by the weight of the overlying rocks by $8-10$ times. The ratio of horizontal stresses to vertical stresses is $0.7-0.8$. The zone of increased stresses in the mass depth by a depth greater than the height of the mountains changes to the zone IV of equal stresses where the erosion cutting of the river and exogenous processes practically have not influenced on the values and distributions of natural stresses. In this zone, horizontal stresses in value are close to or exceed vertical stresses. 


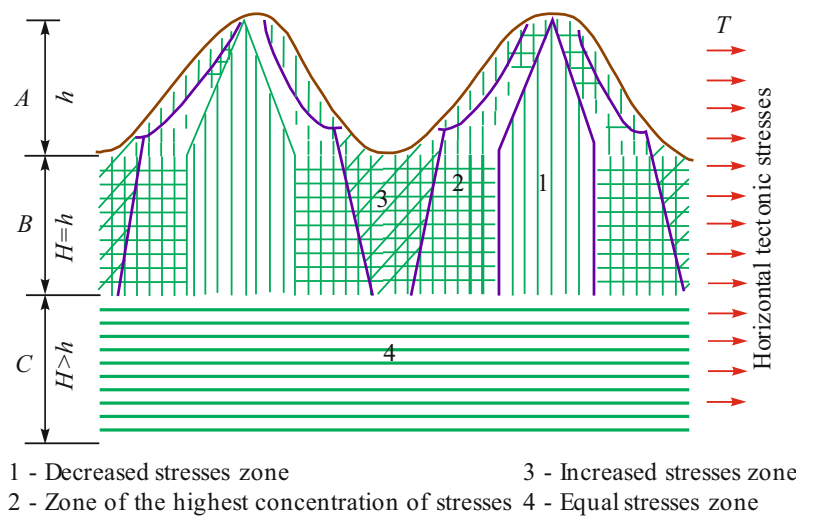

Fig. 7. Stresses distribution in the mass of the slope, under the mountain $[24,26,70]$.

The highest stresses concentration is noted in the lower part of the slope and at the bottom of the valley in the zone III, which is confirmed by the data from the practice of building the hydraulic structures and roads in deep valleys, and surface mining of minerals.

In the example of building the Kirov water storage reservoir on the mountain river Talas in the lower part of the cutting in strong hard rocks, rather intensive rocks destruction was observed in the form of fractures formation and bumps. At the same time, as concrete was laid, as a result of the stresses concentration redistribution, the zone of fractures formation has moved up. The practice of surface mining of minerals and building the mountain roads evidences that mine rocks in the lower part of quarry slopes and mine workings are destroyed by cutting under the action of shear stresses. This means that with respect to local destruction, as well as stability of mountain slopes and quarry slopes, mountain roads, the values of shear stresses in their lower part are the most interesting.

Consequently, the different stress state of the rocks in different zones of the hard rock mass also determines the development in them of various engineering-geological (slips, falls, displacements, etc.) and mining-geological (impacts, outbursts, collapses, etc.) processes. In many respects it determines the work character of the bedrock base, mass slopes and the necessary set of engineering measures to ensure the reliability of the structure.

Calculations and experiments [24, 26, $75-77]$ have proved that the terrain relief affects the stress state of virgin mass. It has been revealed, in particular, that the stress components at the same depth in the same type of mass are different depending on the terrain relief. With flat terrain relief, a uniform, hydrostatic distribution of stresses is observed, and with rough terrain relief it is non-uniform. Moreover, the rougher the surface relief, the greater the difference in stress components.

The influence of the ridges on the mass stress state extends to $1.0-2.0$ of the mountain height. In width, the significant mountain influence extends approximately to a distance htga. The increment of the resultant overload caused by the mountain remains constant with a change in depth, but extends to an ever-increasing area, that is, the disturbance damps with a depth. This explains the destruction of some areas, observed in the mines and pits of Kyrgyzstan. Thus, at the Kadamdzhaysk field, despite the fact that the calculated loads on the pillars are by 1.45 times less than the permissible, in some areas immediately after mining, the pillars were destroyed, followed by intensive roof collapse.

Comparisons have shown $[24,26,65,66,78]$ that the horizontal stresses in the highland conditions are by $1.4-1.5$ times, and the vertical ones are by 1.3 times greater than in the flat conditions. Consequently, the values of the loads on the pillars are by 1.3 times higher, taking into account the relief. This was the reason for the destruction. 
The results of mass stresses measured in-situ at different mines horizons [36] indicate the occurrence of compressive stresses acting in the horizontal direction, their value depending on the direction varies from 130 to $270 \mathrm{~kg} / \mathrm{cm}^{2}$. In the areas of deposits, sharp anisotropy of horizontal stress is observed with prevailing compression in the meridional direction.

Fig. 8 shows curves of the stresses distribution in the mass near a single mine working. Mass has a number of fractures and faults of various thicknesses, at different angles to the well axis, as well as different filling. Fig. 8 shows that near the fractures, a sharp change in stresses concentration occurs. Moreover, the stresses directed in the horizontal direction change their sign to the opposite and by value are greater than vertical ones.

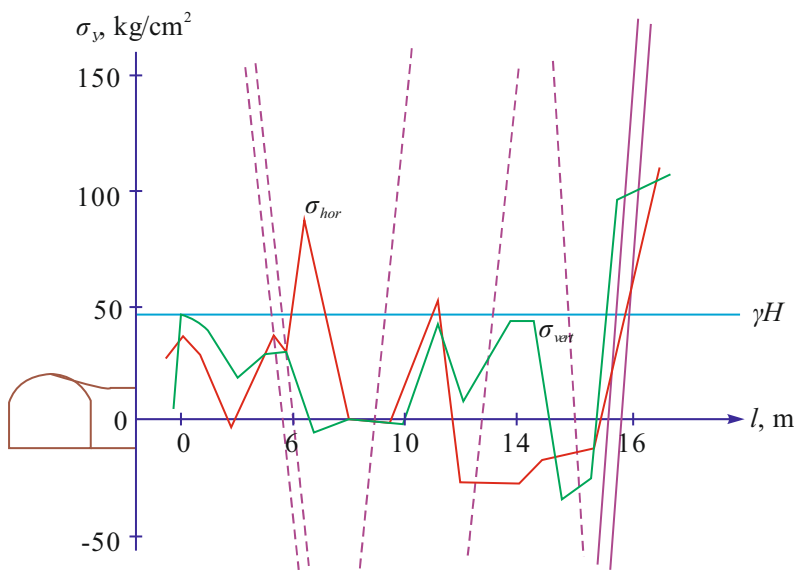

Fig. 8. Stresses distribution in the fractured mine rocks mass.

Based on the measurement results analysis by a combination of factors (exceeding the maximum vertical stresses, $\gamma H$ the absence of tensile stresses near the roof contour), the measured stresses can be considered as tectonic. To study the link of tectonics with specific data of stresses direct measurement at the fields of Kyrgyzstan, information on tectonics, seismicity and geomorphology of the territory of the republic and the area of the Khaidarkan field is used [79-82].

The Khaidarkan field is latitudinally elongated along the foot of the Katran-Too ridge and confined to the Ishme-Too ridge. A number of main folded structures of the same order are observed at the field, on the wings of which additional folds are developed. It should be noted that the main folds are additional formations on the wings of folds of a higher order. Discontinuous disturbances of various orders are developed at the Khaidarkan field: blowouts, overlap faults, and hade faults. Discontinuous disturbances in relation to the countries of the world and the deposits main structures can be divided into three groups: latitudinal, diagonal and meridional.

Mine rocks mass are broken by fractures, often in separate areas they are completely fragmented and crushed. Eight main fracture systems are developed in the area of the field, which are distinguish relative to elements of the seams bedding (Fig. 9).

At the field, the relation of small fractures with tectonic forms and the host rocks composition is clearly observed. Fractures of the I and II systems depend on the forms folding. Their fall, both on the wings and in the fold axis, always occurs over the seam thickness. Propagation of the II system fractures depends on the rocks strike. The intensity of their development increases in the folds' axial areas.

The III and IV fracture systems are studied together, since with respect to the folds they are directed in the same way. Their direction depends on the fold axes course. 


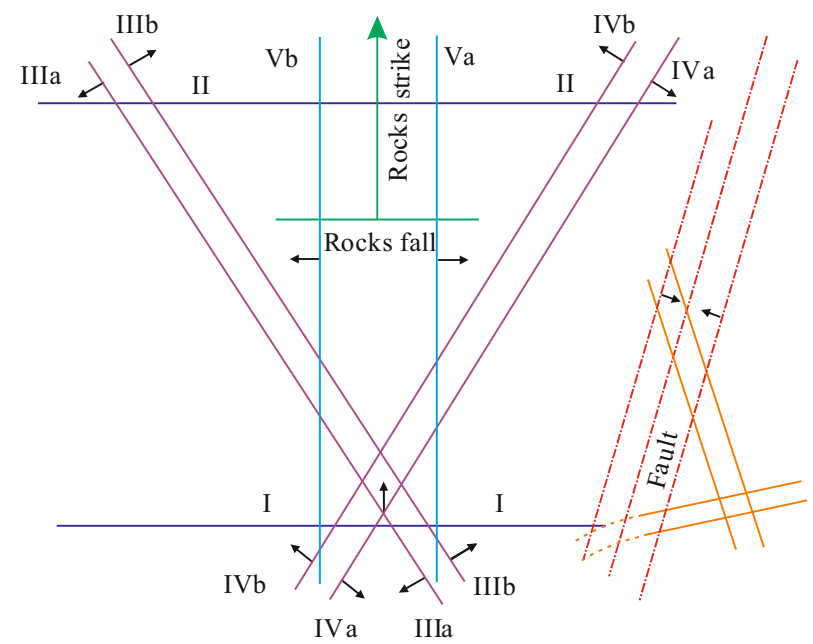

Fig. 9. Main systems of rocks fractures at the Khaidarkan field.

Propagation of the $\mathrm{V}$ fracture system also depends on the folds' direction and an increase in the intensity of these fractures occurs in the areas of manifestation of brachyaxis folding. Wherein, when the fold axis is plunged to the east, fractures of $\mathrm{Vb}$ group are more developed, when plunged to the west, fractures of Va group are developed.

The fractures of VI, VII, VIII systems are genetically related to discontinuous disturbances and occur mainly in the immediate vicinity of them, which indicates the influence of faults on the development of small fractures. When removing from the discontinuous disturbance, the specific rocks fracturing decreases (Table 1).

Table 1. Specific fracturing when removing from the discontinuous disturbance.

\begin{tabular}{|c|c|c|}
\hline Rock & Distance from disturbance, $\mathrm{m}$ & Specific fracturing \\
\hline Coarsely-stratified & $0.8-1$ & 55 \\
\hline Silicified & $2-3$ & 42 \\
\hline \multirow{3}{*}{ Limestone } & $6-7$ & 34 \\
\cline { 2 - 3 } & $10-11$ & 23 \\
\cline { 2 - 3 } & $14-15$ & 21 \\
\cline { 2 - 3 } & $14-20$ & 20 \\
\hline
\end{tabular}

The interrelation of folded and discontinuous disturbances on the example of a particular deposit suggests that, with respect to low forms, the higher ones are determining and primary. This is expressed in the similarity of dependences of the discontinuous disturbances and the rocks strike. The rocks strike depends on the spatial position of the folded forms. The analogies in the strike of large disturbances and small fractures are revealed with respect to the rocks strike. The similarity in the deformation pattern is best manifested in rocks close by their lithological composition.

Thus, the scheme of deformations is observed in the latitudinal plan and is repeated in almost all details on a smaller scale. This proves that the mass are in a stressed state, which often reaches the break-down point of the rocks composing them [83 - 85].

It should be noted that the absolute age of the rocks, given in-situ measurements, is calculated according to geochronology for 50-55 million years. Therefore, according to tectonophysics assessments, the residual stresses in these rocks practically do not remain. However, according to [85], the Tien Shan mountains system belongs to the IV most mobile and intensely deformable type of the earth's crust areas, where recent stresses in the mass 
should be observed. Therefore, the actual stress state of the studied rock mass of the Khaidarkan field consists of a tensor caused by the weight of the overlying rocks, a tensor associated with the tectonics of the area, and smaller tectonic peculiarities of the measured site.

Analysis of direct measurements of stresses under in-situ conditions, tectonics of the Khaidarkan and Uluu-Too deposits area evidences the presence of horizontal compressive stresses and the existence of a relation between the azimuth of the maximum stresses directions in mine workings and the azimuth of the maximum stresses directions according to seismological data [24, 26, $65-70,73,74]$ for the same areas of Kyrgyzstan (Fig. 10).

$a$

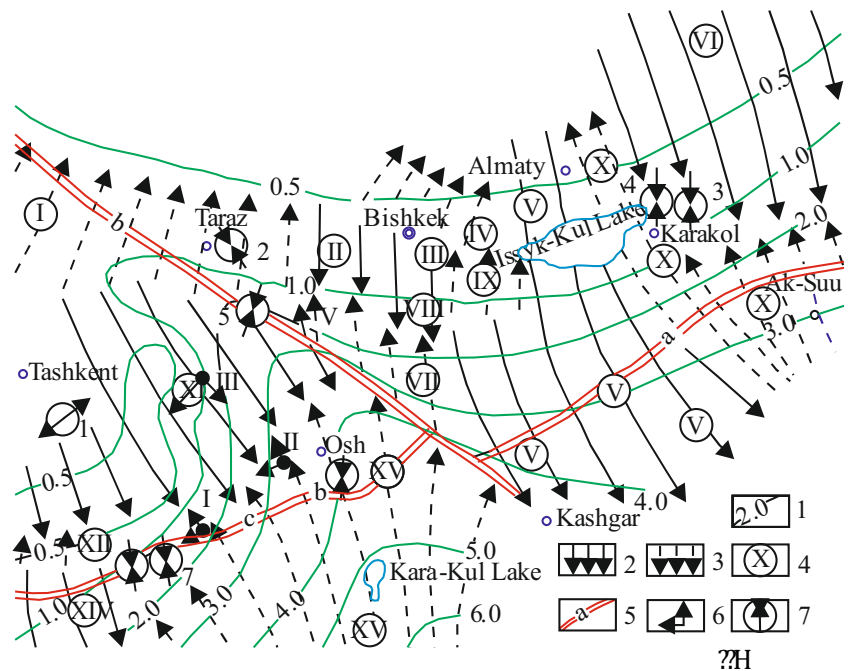

$b$

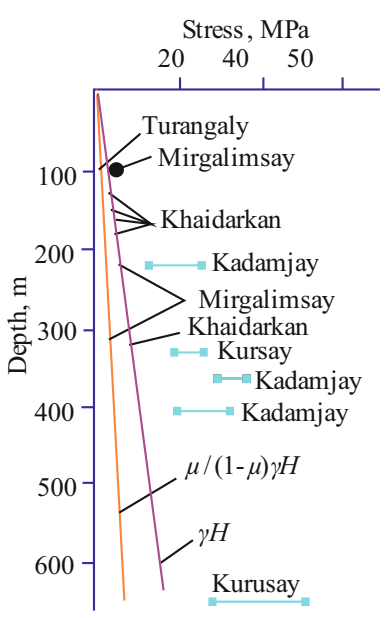

Fig. 10. Directions of the maximum horizontal compressive stresses based on data of the modern earth's crust movement and in-situ measurements: (a) 1 - the average velocities of the earth's crust horizontal movements for the recent time (mm/year); 2, 3- directions of mono-vergent earth's crust movements, oriented toward: 2 - south, 3 -north; 4 -system of mono-vergent structures and their numbers: I - Kara-Too-Talas， II - Asparinsk，III - Chuysk-Kindiktak，IV - Baibiche-Sours，V Trans-Tien-Shan, VI - Dzhungarsk-Tengri-tag, VII - Ketman Tyubinsk, VIII - Jumgalsk, IX Koskorsk, X-Kokshaal-Zailiysk, XI - Chatkal-Ferghana, XII - Nuratau, XIII - Turkestan, XIV Gissar-Baysuntau, XV - Pamir-Alai; 5 - deep-seated faults: a-Kokshaal, b-Talas-Ferghana, cGissar-Vostok-Alai; 6 - directions of the maximum horizontal stresses, measured by the method of unloading: in the mines I - Khaidarkan, II - Uluu-Too, III - Terek-Sai, IV - Toktogul hydroelectric power station; 7 - directions of the maximum compressive stresses according to seismological data: 1 - Tashkent 04/26/66, 2 - Dzhambul 05/10/71, 3 -Sarygamysh 06/05/70, 4 -Zhalanash-Tyupsk 03/03/78, 5 - Chatkal 12/03/77, 6 - Alai 04/04/78, 7 - Batken 02/02/77; (b) - subhorizontal stresses distribution according to measurements in the regional mines.

Experimental works $[24,26,70]$ in different areas (horizon $1730 \mathrm{~m}$ ) of the Khaidarkan field resulted in:

$$
T_{p}=T_{g}+T_{t} \simeq\left|\begin{array}{ccc}
0.93 \gamma H & 0 & -0.03 \gamma H \\
0 & 0.97 \gamma H & 0.03 \gamma H \\
-0.03 \gamma H & 0.03 \gamma H & 1.04 \gamma H
\end{array}\right| .
$$

Similar results are obtained when determining the stress in the mass at the horizon of $1785 \mathrm{~m}$ : 


$$
T_{p}=\left|\begin{array}{ccc}
1.18 \gamma H & 0 & 0.08 \gamma H \\
0 & 1.02 \gamma H & \tau_{y z} \\
0.08 \gamma H & \tau_{z y} & \gamma H
\end{array}\right| .
$$

The vertical component of the stress total tensor is close to the total weight of the rocks in the overlying stratum $(1.0-1.04 \gamma H)$, and the lateral repulse coefficients are $K_{b 1}=0.97-1.02 ; K_{b 2}=0.97-1.02$. Wherein, the greater of the horizontal stresses is oriented in the meridional direction (azimuth $+7^{\circ}-2.30$ ).

In general, the value and direction of the main stresses in the area of Kyrgyz Tien Shan are very diverse and their ratios depend on the geological structure of a particular rock mass section, the tectonic field of stresses and the region relief.

Consequently, the computational methods for assessing the stability of the mass adjacent to mine workings cannot cover the whole variety of factors associated with the mass stress state, since mine working development changes the rock mass stress state in the vicinity of it. Geoacoustic methods are promising in the course of obtaining the relevant information in-situ.

\section{Conclusions}

Stability assessment of the mass adjacent to the mine workings involves determining the stress state of the deposit. Computational and experimental methods for assessing stability do not fully satisfy the demands of practice, firstly, due to the impossibility of considering all the mass structural peculiarities and variable mining-engineering factors, and secondly, due to the high complexity.

The mass stress state should be determined through the values and directions of the main stresses in the mass, which are very diverse under highland conditions, and their ratios depend on the geological structure of a particular rock mass section, the tectonic field of stresses and the region relief.

The obtained patterns and quantitative dependences make it possible to determine the stress state of the virgin mass and the zones of different levels of stresses manifestation and are valuable for designing and planning the development of mining operations.

The different stress state of the rocks in different zones of the hard rock mass predetermines the development in them of various geomechanical processes, in many respects determines the work character of the bedrock base, mass slopes and the necessary set of engineering measures to ensure the reliability of the structure.

The terrain relief affects the stress state of virgin mass. It has been revealed, in particular, that the stress components at the same depth in the same type of mass are different depending on the terrain relief.

The influence of the ridges on the mass stress state extends to $1.0-2.0$ of the mountain height. Horizontal stresses in the highland conditions are by $1.4-1.5$ times, and the vertical ones are by 1.3 times greater than in the flat conditions.

Thus, the conducted research helps to determine not only the dependences on the geological structure, the tectonic field of stresses and the region relief, but also explain the pattern of stresses distribution in the virgin mass. The obtained values of the influence coefficients of the structure and the tectonic field of stresses on horizontal and vertical stresses (increased by $1.4-1.5$ and 1.3 times, respectively) and ridges ( $1.0-.0$ mountain height per depth) are essential to consider the stress state when developing the assessment criteria and geoacoustic control of properties and the state of the rock mass adjacent to mine workings. 
The obtained dependences, with accuracy sufficient for practical application, can be used to predict and assess the mass stress state. In addition, they make possible to use the geoacoustic control method of the properties and state of the rock mass adjacent to mine workings, and involve the highland deposits in mining.

The authors of this work express their sincere gratitude to Mambetov Shergazy Asambaevich, professor of the Kyrgyz Russian Slavic University, for his scientific advising, valuable guidelines and helpful hints. This work has been performed without support of any project and funding.

\section{References}

1. Kovalevs'ka, I., Symanovych, G., \& Fomychov, V. (2013). Research of stress-strain state of cracked coal-containing mass near-the-working area using finite elements technique. Annual Scientific-Technical Collection - Mining of Mineral Deposits, 159-163. https://doi.org/10.1201/b16354-28

2. Bondarenko, V., Cherniak, V., Cawood, F., \& Chervatiuk, V. (2017). Technological safety of sustainable development of coal enterprises. Mining of Mineral Deposits, 11(2), 1-11. https://doi.org/10.15407/mining11.02.001

3. Abdiev, A., Mambetova, R., Abdiev, A., \& Abdiev, Sh. (2020). Studying a correlation between characteristics of rock and their conditions. Mining of Mineral Deposits, 14(3), 87-100. https://doi.org/10.33271/mining14.03.087

4. Pivnyak, G., Bondarenko, V., Kovalevs'ka, I., \& Illiashov, M. (2012). Geomechanical Processes During Underground Mining, 238 p. Book. https://doi.org/10.1201/b13157

5. Sotskov, V., \& Saleev, I. (2013). Investigation of the rock mass stress strain state in conditions of the drainage drift overworking. Annual Scientific-Technical Colletion - Mining of Mineral Deposits, 197-201. https://doi.org/10.1201/b16354-35

6. Mambetov, S.A., Mambetov, A.S., \& Abdiev, A.R. (2002). Zonal and step-by-step evaluation of the stressed-strained state of Tyan'-Shan' rock massif. Gornyi Zhurnal, (10), 57-62.

7. Khomenko, O.Ye. (2012). Energeticheskiy matod issledovaniya zonal'noy dezintegratsii gornykh porod. Naukovyi Visnyk NHU, (4), 44-54.

8. Abdiev, A.R. (2002). Evaluation of the stressed-strained state of rock massif for brown coal deposit in Kara-Keche. Gornyi Zhurnal, (10), 70-72.

9. Dychkovskyi, R. E., Vladyko, O. B., Maltsev, D., \& Cabana, E. C. (2018). Some aspects of the compatibility of mineral mining technologies. Rudarsko Geološko Naftni Zbornik, 33(4).

10. Bondarenko, V.I., Kharin, Ye.N., Antoshchenko, N.I., \& Gasyuk, R.L. (2013). Basic scientific positions of forecast of the dynamics of methane release when mining the gas bearing coal seams. Naukovyi Visnyk Natsionalnoho Hirnychoho Universytetu, (5), 24-30.

11. Malanchuk, Z., Moshynskyi, V., Stets, S., Ignatiuk, I., \& Galiyev, D. (2020). Modelling hydraulic mixture movement along the extraction chamber bottom in case of hydraulic washout of the puffstone. E3S Web of Conference. Preprint.

12. Sobolev, V. V., \& Usherenko, S. M. (2006). Shock-wave initiation of nuclear transmutation of chemical elements. Journal de Physique IV (Proceedings), (134), 977-982. https://doi.org/10.1051/jp4:2006134149

13. Chernai, A.V., Sobolev, V.V., Chernai, V.A., Ilyushin, M.A., \& Dlugashek, A. (2003). Laser ignition of explosive compositions based on di-(3-hydrazino-4-amino-1,2,3-triazole)-copper(II) perchlorate. Combustion, Explosion and Shock Waves, 39(3), 335-339. https://doi.org/10.1023/A:1023852505414

14. Khomenko, O., Kononenko, M., \& Myronova, I. (2013). Blasting works technology to decrease an emission of harmful matters into the mine atmosphere. Annual Scientific-Technical Colletion Mining of Mineral Deposit, 231-235. https://doi.org/10.1201/b16354-43

15. Antsiferov, M.S., Konstantinova, A.G., \& Pereverzev, L.B. (1960). Seysmoakusticheskie issledovaniya v ugol'nykh shakhtakh. Moskva. M.: Izdatel'stvovo AN SRSR. 
16. Beron, A.I., Chirkov, S.E., Pozhidaev, N.I., \& Neustroev, M.V. (1971). Izuchenie vliyaniya napryazhennogo sostoyaniya na skorost' ul'trazvukovykh voln $\mathrm{v}$ gornykh porodakh. Nauchnye soobshcheniya IGD im. A.A. Skochinskogo, (89).

17. Riznichenko, Yu.V., Silaeva, O.I., Shamina, O.G., Myachkin, V.I., Glukhiv, V.A., \& Vinogradov, S.D. (1956). Akusticheskie metody issledovaniya i kontrolya gornykh porod $\mathrm{v}$ massive. Trudy GEOFIAN, (34), 161.

18. Rzhevs'kiy, V.V. (1973). Akusticheskie metody issledovaniya i kontrolya gornykh porod v massive. Moskva: Nauka.

19. Turchaninov I.A., Medvedev R.V., Panin V.I., Kozirev A.A. (1967). Sovremennye metody kompleksnogo opredeleniya fizicheskikh svoystv gornykh porod. Leningrad: Nadra.

20. Turchaninov, I.A., Medvedev, R.V., \& Panin, V.I. (1967). Sovremennye m etody kompleksnogo opredeleniya fizicheskikh svoystv gornykh porod, Gornyy zhurnal, (10).

21. Yamshchikov, V.S. (1982). Metody i sredstva issledovaniya $i$ kontrolya gornykh porod, $i$ protsessov. Moskva: Nedra.

22. Glushko, V.T., Yamshchikov, V.S., \& Yalanskiy, A.A. (1978). Geofizicheskiy kontrol'v ugol'nykh shakhtakh. Kyiv: Naukova dumka.

23. Mambetov, Sh.A. (1978). Geoakusticheskiy kontrol' sostoyaniya massiva porod vblizi gornykh vyrabotok. Izdatel'stvovo Ilim.

24. Mambetov, Sh.A. (1983). Prognozirovanie $i$ kontrol' napryazhenno-deformirovannogo sostoyaniya massiva $v$ vysokogornykh rayonakh $v$ dinamike rabot. Izdatel'stvovo Ilim.

25. Mambetov, Sh.A., Mambetov, A.Sh., \& Abdiev, A.R. (2002). Zonal'naya i poetapnaya otsenka napryazhenno-deformirovannogo sostoyaniya porodnogo massiva Tyan'-Shanya. Gornyy zhurnal, (10), 57-62.

26. Mambetov, Sh.A., Abdiev, A.R., \& Mambetov, A.Sh. (2003). Zonal'naya i poetapnaya otsenka porodnogo massiva Tyan'-Shanya. Bishkek: KRSU.

27. Mambetov, Sh.A., \& Mambetov, A.Sh. (2018). Geoakusticheskie metody izucheniya porodnogo massiva. Bishkek: KRSU.

28. Peyve, A.V., \& Kropotkin, P.N. (1973). Novyy podkhod k izucheniyu napryazheniy v antiklinal'nykh strukturakh Dzhezkazganskogo mestorozhdeniya. Napryazhennoe sostoyanie zemnoy kory.

29. Galushko, P.Ya., Kurenkov, Ya.I., Frenzena, Yu.K., \& Khalimovs'ka, M.A. (1973). Rezul'taty issledovaniy napryazheniy $\mathrm{v}$ massivakh gornykh porod L'vovsko-Volynskogo i Donetskogo ugol'nykh basseynov. Napryazhennoe sostoyanie zemnoy kory.

30. Kurlenya, M.V. (1973). Rezul'taty eksperimental'nykh issledovaniy napryazhennogo sostoyaniya ugol'nykh massivov. Napryazhennoe sostoyanie zemnoy kory, 128-134.

31. Dyakovs'ku, V.B., Chernishov, M.F., \& Pazdnikov, N.V. (1973). Eksperimental'nye issledovaniya napryazhennosti gornogo massiva na Vysokogorskom i Kochkarskom mestorozhdeniyakh. Napryazhennoe sostoyanie zemnoy kory, 107-119.

32. Turchaninov, A.I., Markov, G.A., Ivanov, V. I., \& Kozirev, A.A. (1973). Pole tektonicheskikh napryazheniy po dannym izmereniy v Khibinskom massive. Napryazhennoe sostoyanie zemnoy kory, 50-58.

33. Chabdarova, Yu.I., \& Bukin, A.N. (1973). Eksperimental'nye dannye o pole napryazheniy v antiklinal'nykh strukturakh Dzhezkazganskogo mestorozhdeniya. Napryazhennoe sostoyanie zemnoy kory, 69-76.

34. Shamans'ka, A.T., \& Egorov, P.V. (1973). Sootnoshenie tektonicheskikh elementov s polyami sovremennykh napryazheniy v gornoy Shorii. Napryazhennoe sostoyanie zemnoy kory, 69-76.

35. Vlokh, N.P., \& Sashurin, A.D. (1970). Izmerenie napryazheniy $v$ massive krepkikh gornykh porod. Moskva: Nedra.

36. Mambetov, Sh.A., \& Yalimov, N.G. (1974). Vliyanie tektoniki na napryazhennoe sostoyanie massiva gornykh porod na territorii Kirgizii. Issledovanie po mekhanike gornykh porod. 
37. Turchaninov, I.A., Markov, G.A., Panin, V.I., \& Ivanov, V. I. (1973). Eksperimental'noe opredelenie polnogo tenzora napryazheniy $v$ massive gornykh porod.

38. Kovalevska, I., Zhuravkov, M., Chervatiuk, V., Husiev, O., \& Snihur, V. (2019). Generalization of trends in the influence of geomechanics factors on the choice of operation modes for the fastening system in the preparatory mine workings. Mining of Mineral Deposits, 13(3), 1-10. https://doi.org/10.33271/mining13.03.001

39. Pivnyak, G., Dychkovskyi, R., Bobyliov, O., Cabana, E. C., \& Smoliński, A. (2018). Mathematical and Geomechanical Model in Physical and Chemical Processes of Underground Coal Gasification. Solid State Phenomena, (277), 1-16. https://doi.org/10.4028/www.scientific.net/ssp.277.1

40. Lozynskyi, V., Medianyk, V., Saik, P., Rysbekov, K., \& Demydov, M. (2020). Multivariance solutions for designing new levels of coal mines. Rudarsko Geolosko Naftni Zbornik, 35(2), 23 32. https://doi.org/10.17794/rgn.2020.2.3

41. Slesarev V.D. (1936). Obrushenie i osedanie gornykh porod. Moskva: ONTI.

42. Petlovanyi, M. (2016). Influence of configuration chambers on the formation of stress in multimodulus mass. Mining of Mineral Deposits, 10(2), 48-54. https://doi.org/10.15407/mining10.02.048

43. Sdvizhkova, Ye.A., Babets, D.V., \& Smirnov, A.V. (2014). Analiz zakonomernostey formirovaniya nagruzki na krep' pri proektirovanii montazhnikh kamer strugovykh lav $\mathrm{v}$ usloviyakh shakht Zapadnogo Donbasa. Naukovyi Visnyk NHU, (5). 26-32.

44. Khalymendyk, I., \& Baryshnikov, A. (2018). The mechanism of roadway deformation in conditions of laminated rocks. Journal of Sustainable Mining, 17(2), 41-47. https://doi.org/10.1016/j.jsm.2018.03.004

45. Shashenko, A., Gapieiev, S., Solodyankin, A. (2009). Numerical simulation of the elastic-plastic state of rock mass around horizontal workings. Archives of Mining Sciences, 54(2), 341-348.

46. Kuznetsov, G.N. (1970). Analiticheskie raschety na baze mekhaniki razdel'no-blochnoy sredy, (78), 13-36.

47. Babets, D.V., Sdvyzhkova, O.O., Larionov, M.H., Tereshchuk, R.M. (2017). Otsinka stiikosti masyvu hirskykh porid, shcho bazuietsia na ymovirnisnomu pidkhodi ta reitynhovykh klasyfikatsiiakh. Naukovyi visnyk NHU, (2), 58-64.

48. Vlasenko, B.V., \& Grits'ko, G.I. (1965). Opredelenie napryazheniy v porodakh po izvestnym smeshcheniyam ikh nad plastom i v vyrabotannom prostranstve. Fiziko-tekhnicheskie problemy razrabotki poleznykh iskopaemykh, (6), 35-44.

49. Cherniaiev, O.V. (2017). Systematyzatsiia nerudnykh rodovyshch skelnykh korysnykh kopalyn dlia vdoskonalennia tekhnolohii yikh vidpratsiuvannia. Naukovyi Visnyk NHU, (5), 11-17.

50. Dryzhenko, A., Moldabayev, S., Shustov, A., Adamchuk, A., \& Sarybayev, N. (2017). Open pit mining technology of steeply dipping mineral occurences by steeply inclined sublayers. International Multidisciplinary Scientific GeoConference Surveying Geology and Mining Ecology Management, SGEM, 17(13), 599-606. https://doi.org/10.5593/sgem2017/13/s03.076

51. Vlasova, E., Kovalenko, V., Kotok, V., \& Vlasov, S. (2016). Research of the mechanism of formation and properties of tripolyphosphate coating on the steel basis. Eastern-European Journal of Enterprise Technologies, 5(5 (83)), 33-39. https://doi.org/10.15587/1729-4061.2016.79559

52. Sejtmuratova, E.J., Arshamov, J.K., Baratov, R.T., Dautbekov, D.O. (2016). Geological and metallogenic features of volcano-plutonic belt Kazakhstan. News of the National Academy of Sciences of the Republic of Kazakhstan, Series of Geology and Technical Sciences, 3(416), 60-86.

53. Arshamov, Y., Seitmuratova, E., \& Baratov, R. (2015). Perspectives of porphyry copper mineralizations in Zhongar-Balkhash fold system (Kazakhstan). International Multidisciplinary Scientific GeoConference Surveying Geology and Mining Ecology Management, 345-350.

54. Erzhanov, Zh.S. (1964). Teoriya polzuchesti gornykh porod i ee prilozhenie. Alma-Ata: Nauka, 175.

55. Erzhanov, Zh.S., \& Egorov, A.K. (1968). Teoriya skladkoobrazovaniya $v$ tolshche gornykh porod. Nauka. KazRSR. 
56. Artikbaeva, Z. K. (1974). Vliyanie tektoniki na napryazhennoe sostoyanie massiva gornykh porod na territorii Kirgizii. Issledovanie po mekhanike gornykh porod, 59-75.

57. Artikbaev, Z.K., \& Mambetov, Sh.A. (1975). Izmerenie uprugikh parametrov anizotropnykh gornykh porod ul'trazvukovym metodom. Gornyy zhurnal, (3).

58. Mikhlin, Y. V., \& Zhupiev, A. L. (1997). An application of the ince algebraization to the stability of non-linear normal vibration modes. International Journal of Non-Linear Mechanics, 32(2), 393-409. https://doi.org/10.1016/s0020-7462(96)00047-9

59. Law, B.E., Ulmishek, G.F., Clayton, J.L., Kabyshev, B.P., Pashova, N.T., \& Krivosheya, V.A. (1998). Basin-centered gas evaluated in Dnieper-Donets basin, Donbas foldbelt, Ukraine. Oil and Gas Journal, 96(47), 74-78.

60. Gornostayev, S.S., Crocket, J.H., Mochalov, A.G., \& Laajoki, K.V.O. (1999). The platinumgroup minerals of the Baimka placer deposits, Aluchin horst, Russian Far East. Canadian Mineralogist, 37(5), 1117-1129.

61. Kalinichenko, V., Pysmennyi, S., Shvaher, N., Kalinichenko, O. (2018). Selective underground mining of complex structured ore bodies of Kryvyi Rih Iron Ore Basin. E3S Web of Conferences, (60), 00041 https://doi.org/10.1051/e3sconf/20186000041

62. Stupnik, M., Kolosov, V., Kalinichenko, V., Pismennyi, S. (2014). Physical modeling of waste inclusions stability during mining of complex structured deposits. Progressive Technologies of Coal, Coalbed Methane, and Ores Mining, 25-30. https://doi.org/10.1201/b17547

63. Stupnik, N., Kalinichenko, V., Pismennij, S., Kalinichenko, E. (2015). Features of underlying levels opening at "ArsellorMittal Kryvyic Rih" underground mine. New Developments in Mining Engineering, 39-44.

64. Sadibakasov, I. (1990). Neotektonika vysokoy Azii. Nauka.

65. Mambetov, Sh.A., Abdiev, A.R., \& Mambetov, A.Sh. (2012). Geomekhanicheskoe obespechenie gornykh rabot $\mathrm{v}$ usloviyakh vysokogor'ya. Nauchno-obrazovatel'nyy i proizvodstvennyy zhurnal Inzhener, 3(4), 29-36.

66. Mambetov, Sh.A., Abdiev, A.R., Izabaev, K.D., \& Raimzhanov, A.A. (2015). Strukturnomekhanicheskie osobennosti porodnogo massiva Tyan'-Shanya i voprosy prognozirovaniya sostoyaniya porodnogo massiva mestorozhdeniy. Vestnik KRSU, 15(9), 191-196.

67. Abdykaparov, C.M., \& Abdiev, A.R. (2002). State and prospects of the development the brown coal deposit in Kara-Keche. Gornyi Zhurnal, (10), 16-19.

68. Abdiev, A.R., Mambetova, R.S., \& Mambetov, S.A. (2017). Geomechanical assessment of TyanShan's mountains structures for efficient mining and mine construction. Gornyi Zhurnal, 23-28. https://doi.org/10.17580/gzh.2017.04.04

69. Mambetov, Sh.A., \& Abdiev, A.R. (2017). Geomekhanicheskoe sostoyanie porodnykh massivov vysokogornykh mestorozhdeniy. Vestnik KRSU, 17(5), 140-143.

70. Mambetov, Sh.A., \& Abdiev, A.R. (2019). Geomekhanicheskoe sostoyanie porodnogo massiva Tyan'-Shanya. Bishkek, Kirgizstan, KRSU.

71. Lyashenko, V. (2018). Safety Improving of Mine Preparation Works at the Ore Mines. Bezopasnost' Truda v Promyshlennosti, (5), 53-59. https://doi:10.24000/0409-2961-2018-5-53-59

72. Kostyuk, A.D., Sichova, N.A., Yunga, S.L., \& Bogomolov, L.M. (2010). Deformatsiya zemnoy kory severnogo Tyan'-Shanya po dannym ochagov zemletryaseniy i kosmicheskoy geodezii. Fizika zemli, (3), 52-65.

73. Abdiev, A.R. (2002). Zonal'naya i poetapnaya otsenka napryazhenno-deformirovannogo sostoyaniya porodnogo massiva Tyan'-Shanya. Gornyy zhurnal, (10), 70-72.

74. Abdikaparov, Ch.M., \& Abdiev. A.R. (2002). Sostoyanie i perspektivy osvoeniya burougol'nogo mestorozhdeniya Kara-Keche. Gornyy zhurnal, (10), 16-18. Moskva, Rosiya, Ruda i metali.

75. Aytmatov, I.T., Vdovin, K.D., \& Kozhogulov, K.Ch. (1976). Nekotorye rezul'taty izmereniya napryazheniy v predelakh Kurusay-Turanglinskogo rudnogo polya. Izmereniya napryazheniy $v$ massive gornykh porod, 32-35. 
76. Kirgizstan, I, Aytmatov, I.T., Vdovin, K.D., \& Yalimov, N.G. (1978). Eksperimental'nye issledovaniya napryazhennogo sostoyaniya massiva gornykh porod na mestorozhdeniyakh Sredney Azii. Izvestiya AN KSSR, (4), 34-38.

77. Yalimov, N.T., Mambetov, Sh.A., Shikiryanskiy, S.M., Aymautov, A.E., Artikbaev, Z.K., Beglyakov, V.E., \& Zincheko, A.S. (1973). Rezul'taty sravnitel'nykh izmereniy napryazheniy $v$ massive gornykh porod. Izmerenie napryazheniy $v$ massive gornykh porod. N.: Nauka.

78. Gharouni-Nik, M. (2006). Assessment of in-situ initial rock stress in underground powerhouse cavern of Karun dam. In-Situ Rock Stress, 333-340.

79. Aytmatov, I.T., Vdovin, K.D., \& Kozhogulov, K.Ch. (1976). Nekotorye rezul'taty izmereniya napryazheniy $\mathrm{v}$ predelakh Kurusay-Turanglinskogo rudnogo polya. Izmereniya napryazheniy $v$ massive gornykh porod, (2), 32-35.

80. Abdiev, A.R., Mambetova, R.Sh., Abdiev, A.A., \& Abdiev, Sh.A. (2020). Aktual'nye voprosy kontrolya sostoyaniya porodnogo massiva vokrug gornoy vyrabotki. Zhurnal nedropol'zovanie XXI vek, 2(85), 82-91.

81. Abdiev, A.R., Mambetova, R. S., \& Abdiev, A.A. (2020). Study of deformations of rock mass of high mountain deposits, forecast and control of their geomechanical condition. Scientific Development Trends and Education, (60), 51-57. https://doi.org/10.18411/lj-04-2020-162

82. Abdiev, A.R., Mambetova, R.S., \& Abdiev, A.A. (2020). Improving the technology and organization of geological exploration exploited complex structural deposits. Scientific Development Trends and Education, (60), 57-64. https://doi.org/10.18411/li-04-2020-163

83. Abdiev, A.R. (2020). Development of forecasting methods for geomechanical processes in rock mass arrays. Problemi nadrokoristuvannya, (1), 49-55. https://doi.org/10.25635/23131586.2020.01.049

84. Abdiev, A.R. (2020). Forecasting and estimation of geomechanical processes in rocks masses of a deposit. Problemi nadrokoristuvannya, (1), 56-64. https://doi.org/10.25635/23131586.2020.01.056

85. Gzovskiy, M.V. (1972). Tektonicheskie predstavleniya o napryazhennom sostoyanii zemnoy kory. Leningrad: Nauka. 